\title{
Relevansi Kurikulum Pendidikan Vokasi Dengan Usaha Jasa Perjalanan Wisata Di Makassar, Jakarta dan Bali
}

\author{
Amirullah'*, Margaretha Wadid Rante ${ }^{2}$, Muhammad Rusdi ${ }^{3}$ \\ ${ }^{123}$ Politeknik Pariwisata Makassar \\ ${ }^{1}$ Email: amirullahakpar@gmail.com, ${ }^{2}$ Email:Ethapoltekpar@gmail.com, \\ ${ }^{3}$ Emai: rusdipoltekpar@gmail.com \\ *Corresponding author
}

\begin{abstract}
Vocational curriculum is a demand that a university should have. It consists of subjects taught, and credit of semester. This research aims at 1) understanding the description of travel industry in the 4.0 era; 2 ) understanding the vocational curriculum at study program of travel business of Makassar Tourism Politechnic; 3) understanding the need of human resources in Makassar, Jakarta and Bali. This paper employs a qualitative methodology. Informants consists of eight people who work at the tourism and travel industry. Data were analysed based on the principle of reduction. The research reveals that curriculum at travel business department should be in paraller with the need of human resourses in Makassar, Jakarta and Bali.
\end{abstract}

Keywords: Vocational curriculum, curriculum relevance, travel business

\begin{abstract}
Abstrak. Kurikulum vokasi merupakan suatu tuntutan atau pedoman yang harus diikuti oleh setiap perguruan tinggi vokasi, yang terdiri atas susunan matakuliah, sistem kredit semester yang dituangkan dalam pembelajaran semester pada Politeknik Pariwisata Makassar. Penelitian ini bertujuan untuk mengetahui (1) gambaran industri jasa perjalanan wisata era industry 4.0, (2) kurikulum vokasi pada Program Studi Usaha Perjalanan Wisata Politeknik Pariwisata Makassar, dan (3) kebutuhan sumber daya manusia industri jasa perjalanan wisata di Makassar, Jakarta dan Bali. Penelitian ini menggunakan pendekatan deskriptif kualitatif. Jumlah informan sebanyak delapan orang. Teknik pengumpulan data menggunakan teknik wawancara. Data yang telah dikumpulkan diolah, direduksi, dan disimpulkan. Hasil penelitian menunjukkan bahwa pentingnya kurikulum Usaha Perjalanan Wisata Politeknik Pariwisata Makassar menyelaraskan dengan kebutuhan sumber daya manusia usaha perjalanan wisata di Makassar, Jakarta dan Bali.
\end{abstract}

Kata Kunci: Kurikulum vokasi, relevansi kurikulum, usaha jasa perjalanan

\section{PENDAHULUAN}

Indonesia merupakan negara yang banyak memiliki kekayaan alam. Bahkan beberapa kekayaan alam Indonesia tidak dimiliki oleh negara lain. Seperti emas, gas alam, batubara hingga pariwisata. Dengan kekayaan sumber daya alam yang melimpah di Indonesia harus selaras dengan sumber daya manusia yang memiliki kompetensi yang handal di bidangnya masing-masing.

Pada hakikatnya kehadiran pariwisata di Indonesia memberikan pengaruh kepada semua lapisan masyarakat, karena pariwisata memiliki "multiplayer effect", artinya pariwisata memberikan pengaruh yang luar biasa bagi semua lapisan masyarakat baik pengaruh yang berdampak langsung maupun tidak langsung. Pengembangan yang terencana secara menyeluruh, sehingga dapat diperoleh manfaat yang optimal bagi masyarakat, baik dari segi ekonomi, sosial, maupun kultural. Perencanaan tersebut harus mengintegrasikan pengembangan pariwisata kedalam suatu program pembangunan ekonomi, fisik, dan sosial dari suatu negara. Di samping itu rencana tersebut harus mampu memberikan kerangka kerja kebijakan pemerintah dalam rangka mendorong dan mengendalikan pengembangan pariwisata sehingga dampak positif bias dimaksimalkan dan dampak negative diminimalkan (Geriya 1983: 56-57).

Salah satu usaha jasa perjalanan wisata 
dalam pariwisata yang terkandung dalam Undang-Undang Kepariwisataan No 10 tahun 2009 ada Biro perjalanan wisata. Biro perjalanan wisata saat ini yang ada di Indonesia sangat pesat dalam pertumbuhannya, hal ini dipengaruhi oleh system geografi pariwisata yang dapat melihat potensi setiap daerah yang dapat di "jual" oleh biro perjalanan wisata. Biro perjalanan wisata memiliki fungsi sebagai "jembatan" dalam menghubungkan wisatawan dengan daerah tujuan wisata serta beberapa fasilitator dalam komponen paket wisata yang sesuai dengan kebutuhan dan keinginan wisatawan sebagaimana usaha agen perjalanan wisata meliputi usaha jasa pemesanan sarana, seperti pemesanan tiket dan pemesanan akomodasi serta pengurusan dokumen perjalanan(Ismayanti 2010:113). Hal sangat terpenting dalam keberlangsungan dari biro perjalanan wisata selain dari asset sumber daya pariwisata adalah sumber daya manusia yang memiliki attitude, knowledge dan skill yang sangat mumpuni di bidangya.

Sumber daya manusia (SDM) pariwisata merupakan individu/pelaku industri pariwisata yang secara langsung ataupun tidak langsung memiliki interaksi/keterkaitan dengan seluruh komponen periwisata. SDM pariwisata memegang peranan penting dalam menggerakkan roda industri ini. Dengan memiliki Sumber Daya Manusia pariwisata yang memiliki kompetensi yang baik, maka pembangunan pariwisata dapat dilakukan secara optimal. Pariwisata merupakan kegiatan yang memiliki saling berhubungan dan keterkaitan yang tinggi dengan bidang dan sektor lain baik secara lintas sektoral maupun lintas regional (kewilayahan). Hubungan dalam konteks lintas sektor yang mencakup aspek pemanfaatan sumber daya, dukungan sarana prasarana dan infrastruktur, sumber daya manusia, kebijakan kemudahan perizinan, investasi, serta bentukbentuk regulasi lainnya.

Penelitian ini bertujuan untuk mengetahui gambaran industri jasa perjalanan wisata era industri 4.0, kurikulum vokasi pada Program Studi Usaha Perjalanan Wisata Politeknik Pariwisata Makassar, dan kebutuhan sumber daya manusia industri jasa perjalanan wisata Makassar, Jakarta dan Bali berdasarkan konsep operator usaha perjalanan wisata yang menangani/merancang.

Relevansi adalah kesesuaian antara kemampuan atau skill yang diperoleh melalui jenjang pendidikan dengan kebutuhan pekerjaan
(Ali, 2009). Secara umum Kurikulum merupakan seperangkat atau sistem rencana dan pengaturan mengenai isi dan bahan pembelajaran yang dipedomani dalam aktivitas belajar mengajar. Secara etimologis kurikulum berasal dari istilah curriculum dimana dalam bahasa Inggris, kurikulum. Menurut UndangUndang No.20 Tahun 2003 kurikulum adalah seperangkat rencana tujuan pendidikan nasional. Peraturan Menteri Pariwisata Republik Indonesia No. 6 tahun 2017 Tentang Kurikulum berbasis Kompetensi Program Pendidikan Tinggi di Lingkungan Kementerian Pariwisata.

Menurut Edi F. dan Yufridawati (2010) pendidikan yang relevan adalah pendidikan yang memiliki relevansi kualitatif yang menyangkut masalah keserasian peranan sekolah sebagai lembaga sosialisasi dan kulturalisasi untuk mencapai visi dan misi pendidikan sekolah. Relevansi juga merupakan keserasian hasil pendidikan secara kuantitatif dengan jenis keahlian yang dibutuhkan masyarakat, sehingga masalah relevansi dikaitkan dengan jenis pendidikan yang direncanakan dalam hubungannya dengan dunia kerja. Menurut Soedijarto (2008) dalam Edi F. dan Yupridawati (2010) ada dua jenis relevansi yang berhubungan dengan karakteristik dan kualitas hasil belajar yaitu: (1) relevansi epistemology berhubungan dengan masalah bentuk komunikasi antara pembelajar dengan obyek yang dipelajari dan (2) relevansi psikologis yang berhubungan dengan masalah jenis aktivitas belajar.

Kurikulum dapat disimpulkan bahwa relevansi kurikulum merupakan kesesuaian/ keserasian antara apa yang diajarkan di lembaga pendidikan dengan visi dan misi lembaga pendidikan yang mengacu pada tujuan endidikan nasional. Kurikulum harus sejalan dengan lingkungan peserta didik, tuntutan kehidupan peserta didik dan tuntutan karier peserta didik, berkaitan dengan kurikulum yang terdapat di Politeknik Pariwisata Makasssar, Program Studi Usaha Perjalanan Wisata Diploma 4 pada khususnya dalam meningkatkan mutu pendidikan relevansi kurikulum sangat diperlukan dalam kemampuan sekolah membentuk kompetensi lulusan agar menjadi tenaga kerja yang produktif dan berjiwa kompetitif secara global.

HASIL PENELITIAN DAN
PEMBAHASAN


Gambaran usaha perjalanan wisata pada era industri 4.0

Dalam mempertahankan eksistensi sebagai "bridge" antara Wisatawan dengan destinasi, sebagai pelaku dan penyedia jasa pariwisata di negara Indonesia. Keberadaan usaha perjalanan wisata seperti Biro Perjalanan Wisata terus bergerak, focus dan selalu melakukan inovasi yang terintegrasi dengan tuntutan pasar (Market Oriented), Informasi dan tentu saja keberadaan akan teknologi.

Berdasarkan beberapa informan pelaku usaha perjalanan wisata yang ditemui untuk melaksanakan interview di antaranya Hakam manager pada Dhifa Tour and Travel Makassar memaparkan perlunya peserta didik dibekali dengan pengalaman serta kompetensi, dan saat ini biro perjalanan wisata yang berada di Makassar terus menempa dan meningkatkan kemampuannya dalam menjadi pemain dalam meningkatkan kunjungan wisatawan ke Indonesia. Robert A. manager dari Wira Tours Makassar memaparkan bahwa inovasi dari ketersediaan sumber daya manusia yang terjun ke industri pariwisata harus memperkaya dan terus melakukan pembaharuan dari sisi kompetensi (attitude, knowledge dan skill). Dengan keberadaan Usaha Perjalanan Wisata yang terus ingin berkiprah dan menunjukkan eksistensinya dukungan utama berasal dari asetnya yaitu Sumber Daya Manusia dalam hal ini Peserta dari Program Studi Usaha Perjalanan Wisata Diploma 4 yang berkiprah dalam usaha perjalanan wisata harus dibekali dengan kemampuan dan terlatih (bersertifikasi). Sehingga Biro perjalanan wisata dapat mengembangkan usahanya secara kompetensi, unik dan berkarakteristik, serta memberikan pelayanan maksimal.

Kaleb Yusuf Sinay salah seorang staf perusahaan Start $U p$ Airy Jakarta dalam wawancaranya mengatakan bahwa Sumber daya manusia saat ini wajib memiliki kemampuan dalam hal digital dan kemampuan teknologi karena pada dasarnya Start $U p$ merupakan Perusahaan yang berbasiskan aplikasi teknologi (Software) sehingga sumber daya manusia yang dibutuhkan dalam skala kompetensi yang handal dan dapat melakukan analisa pasar. Product knowledge hal yang kedua dalam kemampuan yang wajib dimiliki oleh Sumber daya manusia dalam lingkungan Start up ini berkaitan dengan background pendidikan sumber daya manusia tersebut sehingga dapat mengetahui kekurangan dan kelebihan dari produk yang akan di jual oleh perusahaan tersebut. You built your own business platform yang digunakan oleh Start Up karena dalam Environment Start Up sangat menitiberatkan akan kepemimpinan diri sendiri dan penyelesaian tugas/job desk oleh staf bersangkutan.

Pelaksanaan proses belajar dan mengajar pada Program Studi Usaha Perjalanan Wisata Diploma 4 terlaksananya kegiatan tersebut belum mencapai "kepuasaan" terhadap peserta didik. Hal ini terjadi dengan masih belum memadainya integrasi teknologi dalam hal ini berbasis digitalisasi yang diterapkan. Kompetensi dari peserta didik belum memadai dari pemenuhan kapasitas Operasional, Pelayanan dan finansial dalam hal pembelajaran. Hal ini terjadi dikarenakan komposisi kurikulum yang begitu padat sehingga mata kuliah tidak terintegrasi satu dengan yang lainnya, pelaksanaan Student Internship Programm hanya dilaksanakan satu kali yaitu pada semester 4 dan 5 saja. Sehingga kemampuan yang bersifat Operasional, Pelayanan dan Finansial kurang dipahami dan diaplikasikan oleh peserta didik pada saat berada di industry perjalanan wisata pada khususnya.

\section{Kurikulum Vokasi pada Program Studi Usaha Perjalanan Wisata Politeknik Pariwisata Makassar}

Perkembangan pariwisata saat ini memiliki potensi yang terus dapat dikembangkan. Salah satu rencana panjang pemerintah Indonesia adalah mendatangkan wisatawan mancanegara sebanyak 20 juta wisatawan mancanegara pada tahun 2019 melalui pengembangan Kawasan Strategis Pariwisata Nasional atau yang lebih dikenal dengan Ten New Bali. Politeknik Pariwisata Makassar merupakan salah satu Perguruan Tinggi Negeri Pariwisata yang berada di bawah naungan Kementerian Pariwisata yang mengambil peran dalam mempersiapkan Sumber daya manusia yang handal dalam bidang pariwisata. Kurikulum, sarana dan prasarana pembelajaran, strategi pembelajaran harus menyusuaikan diri dengan kebutuhan industri saat ini. Penyusuaian yang dimaksud agar lulusan dari Politeknik Pariwisata Makassar agar segera direkrut oleh industri.

Kurikulum yang diterapkan pada

Program Studi Usaha Perjalanan Wisata Diploma 4 menjalankan dua Kurikulum yaitu 
Kurikulum 2014 dan 2017. Kurikulum yang merupakan ditetapkan langsung oleh Kementerian Pariwisata. Berdasarkan hasil observasi dan wawancara dengan Surya akademisi dan asesor BAN-PT dari Sekolah Tinggi Pariwisata Trisakti menjelaskan perkembangan kurikulum yang terkait dengan pemenuhan kapasitas kompetensi outcome dari Program Studi Usaha Perjalanan Wisata Diploma 4. Dijelaskan pula bahwa posisi kurikulum dalam perguruan tinggi vokasi sangat strategis dan memiliki peranan sangat penting dengan melihat perkembangan zaman yang berbasiskan teknologi sehingga kurikulum harus selalu menyesuaikan diri dengan tuntutan era industri pariwisata 4.0.
Pemaparan data yang dilakukan oleh peneliti mengenai kesenjangan yang terjadi pada saat pelaksanaan Student Internship Programm. Data-data berikut mencakup peserta didik yang melakukan Student Internship pada Kota Makasar, Bali dan Jakarta, berikut pemaparan data - data tersebut.

Kegiatan Student Internship Program rata-rata pada usia 20-29 hal ini dikarenakan kegiatan Student Internship Program dilaksanakan oleh peserta didik pada saat semester 4 dan 5 dari 8 (delapan) jumlah semester yang harus dilalui oleh peserta didik dalam menyelesaikan studinya di Program Studi Usaha Perjalanan Wisata Diploma 4 pada Politeknik Pariwisata Makassar.

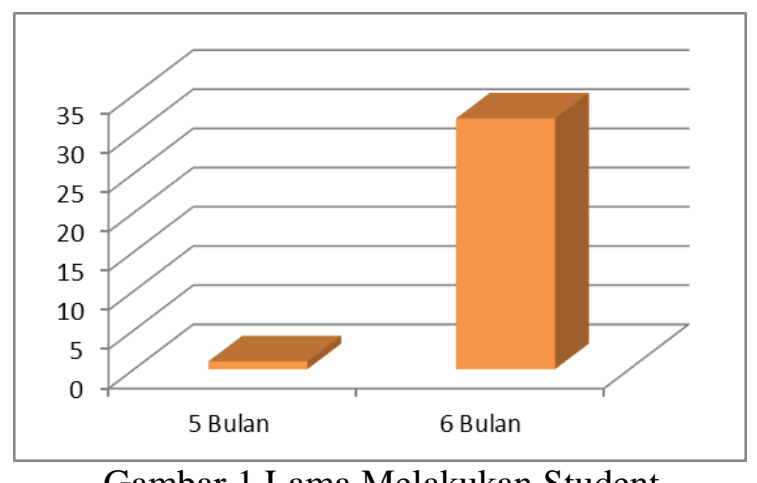

Gambar 1.Lama Melakukan Student Internship Program (SIP)

Berdasarkan gambar 1 peserta didik melakukan kegiatan Student Internship Program selama 6 (enam) bulan. Lama atau periode dalam pelaksanaan kegiatan Student Internship Programm berkaitan dengan pemenuhan "Capacity Building" baik dari pemenuhan Attitude, Knowledge dan Skill yang didapatkan pada saat melakukan Student Internship Program. Namun lama periode pelaksanaan kegiatan Student Internship Program tidak menjamin peserta mendapatkan pengalaman yang sama dan pemenuhan Attitude, Knowledge dan Skill di industry. Kurangnya kepercayaan diri dari peserta didik, terbatasnya ilmu yang dibekali dari bangku kuliah bahkan ketidakpercayaan pihak industri pada peserta didik yang sedang melaksanakan Student Internship Programm.

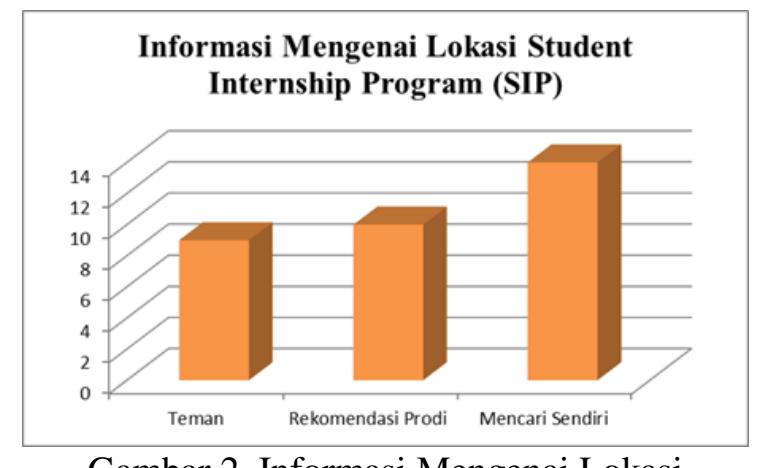

Gambar 2. Informasi Mengenai Lokasi

Student Internship Program (SIP)

Berdasarkan gambar 2 menunjukkan bahwa pelaksanaan kegiatan Student Internship Programm yang dilaksanakan kurang lebih selama 6 (enam) bulan dapat membantu mahasiswa dalam peningkatan Attitude, Knowledge dan Skill. Dalam penempatan peserta didik di industri perjalanan wisata pihak Program Studi Usaha Perjalanan Wisata 
membantu Pihak Administrasi Kemahasiswa Poliktenik Pariwisata Makassar dalam mencari Lokus Student Internship Program, selain itu pihak program studi memberi keleluasaan kepada peserta didik dalam mencari sendiri Industri Perjalanan wisata atau lokus Praktik
Kerja Nyata sendiri untuk melatih korespondensi peserta didik dengan pihak industry serta mengetahui minat dari peserta didik untuk mengembangkan pengetahuan dan pengalaman di industri perjalanan wisata.

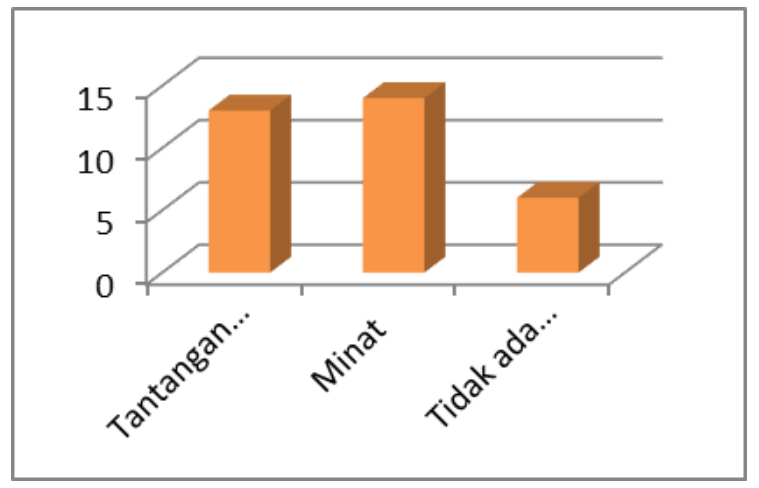

Gambar 3. Motivasi Pemilihan Lokasi

Student Internship Programm (SIP)

Berdasarkan Gambar 3 menunjukkan peserta didik dalam melaksanakan kegiatan Student Internship Programm memiliki motivasi untuk mendapatkan Lokus Kegiatan Student Internship Programm sesuai dengan minat masing-masing peserta didik. Baik untuk meningkatkan kemampuan dan pengalaman di bidang pelayanan, operasional dan finansial. Namun keterbatasan dalam memperoleh kemampuan dan pengalaman yang didapatkan pada saat berada di industri perjalanan disebabkan kurangnya bekal ilmu dan praktik yang didapatkan selama berada di bangku perkuliahan. Sedangkan untuk motivasi dalam pemilihan lokasi Student Internship Programm bagi peserta didik sebagian ingin mendapatkan tantangan agar ingin mengetahui platform yang ada di industry perjalanan namun keterbatasan itu terjadi dikarenakan bekal kemampuan dari bangku kuliah masih kurang dan kurangnya kepercayaan yang diberikan industry pada peserta didik.

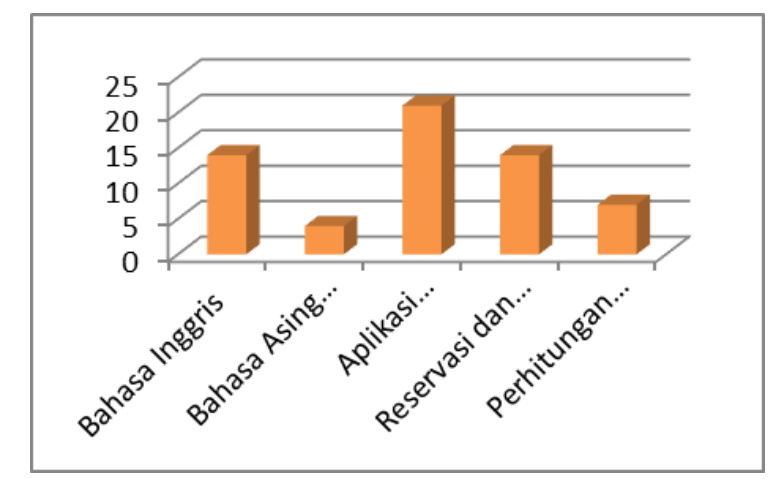

Gambar 4. Mata Kuliah Pendukung saat melakukan

Student Intenship Program (SIP)

Berdasarkan gambar 4 menunjukkan capacity building peserta didik yang sangat membantu pada saat melakukan kegiatan Student Internship Programm. Terlihat pada chart di atas Aplikasi Komputer sangat membantu dalam meningkatkan kemampuan peserta didik pada saat berada di industry perjalanan. Era industry 4.0 menjadi patokan sebuah industri perjalanan dalam menjalankan bisnisnya saat ini. karakteristik sebuah indsutri perjalanan dengan memanfaatkan teknologi dalam hal pelayanan, operasional serta pengolahan finansial perusahaan. Namun mata kuliah yang ada di Program Studi Usaha Perjalanan Wisata khususnya mata kuliah vokasi belum maksimal dalam berintegrasi dengan teknologi. Integrasi teknologi dalam mata kuliah vokasi di Program Studi Usaha Perjalanan Wisata Diploma 4 baik secara materi pembelajaran maupun pelaksanaan praktik di proses pembelajaran. 


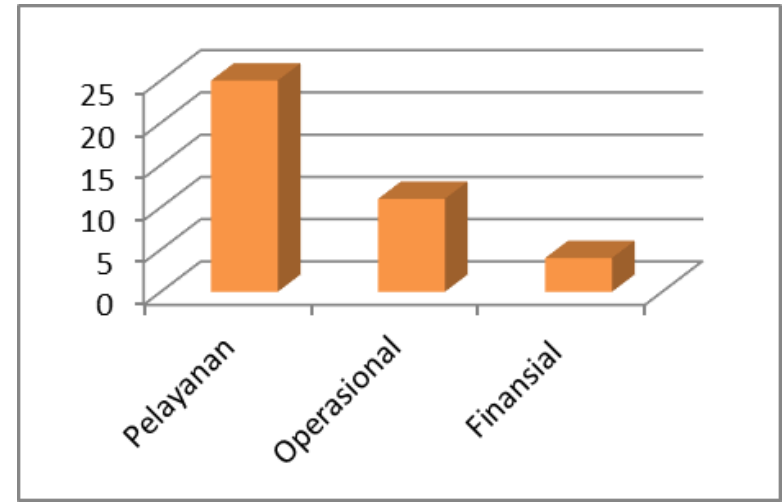

Gambar 5. Kegiatan yang dilakukan pada saat Student Internship Program

Berdasarkan gambar 5 memaparkan kemampuan individu pada saat melaksanakan kegiatan Student Internship Program di Industri perjalanan. Pelayanan menjadi hal utama yang sering dilaksanakan dan dipercayakan pihak industry kepada peserta didik dikarenakan industry perjalanan merupakan industry yang menjual "services" dan didukung kapasitas pengetahuan pelayanan yang diberikan pada saat berada di bangku kuliah sudah maksimal dengan beberapa program yang dijalani peserta didik sebelum berada di industri perjalanan seperti kegiatan Pembentukan Sikap Dasar Profesi dimana peserta didik menempuh kegiatan tersebut selama beberapa hari dengan kegiatan yang diorientasikan dalam melayani wisatawan/pelanggan pada saat berada di industri. Khusus untuk peserta didik pada Program Studi Usaha Perjalanan Wisata beberapa mata kuliah vokasi menuntut peserta didik untuk dapat tampil dan percaya diri di depan orang banyak dengan menggunakan Bahasa Inggris.

Pada kegiatan operasional peserta didik cukup dipercayakan oleh industri perjalanan baik dalam mempersiapkan dokumen perjalanan wisata, menjadi escort dalam melayani wisatawan dan membantu staf di industri perjalanan pada saat perjalanan wisata telah berakhir. Namun dalam pengelolaan finansial peserta didik belum maksimal diberikan kepercayaan dalam mengelola finansial di industri perjalanan hal ini berkaitan dengan finansial merupakan hal yang sensitive bagi perusahaan dan peserta didik belum maksimal dalam mengetahui pengelolaan finansial yang ada di industri perjalanan.

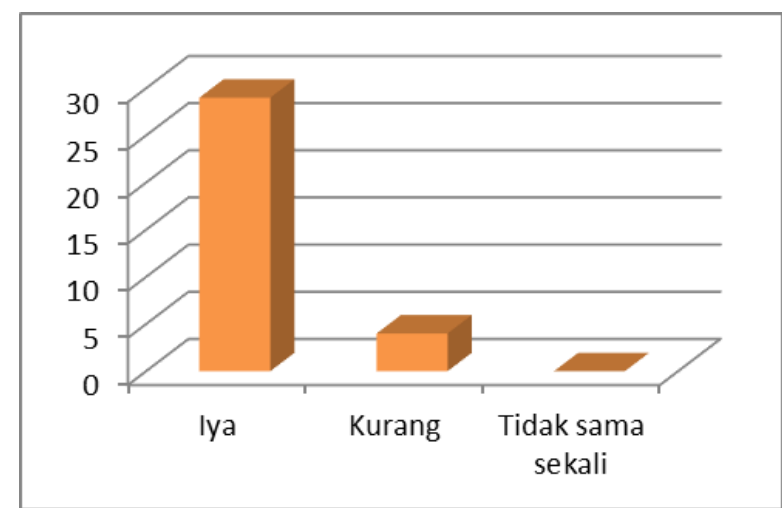

Gambar 6. Lokasi Student Internship Programm dapat Mengembangkan Attitude, Skill dan Knowledge

Berdasarkan gambar 6 menjelaskan mengenai pemilihan Lokasi kegiatan Student Internship Programm yang dapat mengembangkan kompetensi peserta didik dalam hal ini adalah Attitude, Knowledge dan Skill. Dalam pemilihan lokasi Student Internship Programm hampir seluruh mahasiswa dapat pengembangan kompetensi tersebut. Data di atas berkorelasi dengan data kegiatan yang dilakukan pada saat kegiatan Student Internship Programm, mahasiswa dipercayakan oleh pihak industri perjalanan dalam melayani baik staf maupun wisatawan di industri perjalanan. Dan sebagian mahasiswa 
belum dapat mengembangkan Attitude, Knowledge dan Skill kemungkinan faktor yang telah dipaparkan kurang dipercayakan dalam mengelola suatu job desk dan kurang bekal yang didapatkan oleh peserta didik mengenai

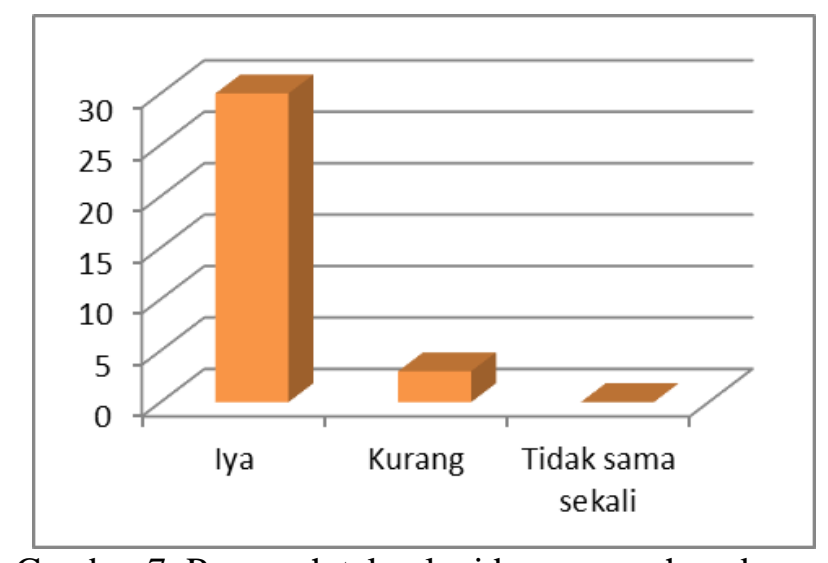

Gambar 7. Pengaruh teknologi berpengaruh pada saat kegiatan Student Intersnhip Programm

Berdasarkan gambar 7 memaparkan pengaruh dari era industri 4.0 yang berdampak pada kurikulum pembelajaran. Teknologi merupakan salah satu "thing" yang sangat membantu peserta didik dalam bersaing pada saat berada di industri perjalanan. Pemahaman teknologi baik secara terminology maupun praktik akan memberikan peluang bagi peserta didik menjadi "leading" pada saat melakukan Student Internship Program. Integrasi Teknologi ini kurang maksimal pada saat pembelajaran berlangsung terutama pada saat mata kuliah vokasi yang ada di Program Studi Usaha Perjalanan Wisata Diploma 4 pada Politeknik Pariwisata Makassar. Mata kuliah vokasi seperti yang menggunakan sistem komputerisasi kurang maksimal dalam penggunaan teknologi sehingga peserta didik kurang memahami terminologi dan praktik yang ada di industri perjalanan

Berdasarkan gambar di atas Bahasa Inggris ini didapatkan mahasiswa baik secara kemampuan mandiri baik didapatkan secara formal dan non-formal di luar lingkungan kampus. Namun kurangnya benchmarking antara pihak akademisi dalam hal ini dosen yang berada di Program Studi Usaha Perjalanan Wisata dengan pihak industri perjalanan sehingga platform dan terminologi di industri perjalanan wisata yang menggunakan Bahasa inggris kurang dipahami oleh peserta didik. Sehingga pada saat peserta didik berada di industri perjalanan dalam melakukan kegiatan Student Internship Programm kurang memahami bahkan tidak dapat menjalankan sistem yang menggunakan Bahasa Inggris. Adapun penilaian peserta didik mengenai hal tersebut menilai kurang hal ini didasarkan karena peserta didik tersebut menjalani kegiatan Student Intersnhip Programm berada pada posisi back office yang dimana jobdesk hanya mengurus mengenai dokumen yang berbahasa Indonesia. Selain itu mahasiswa yang menilai kurang menjalani kegiatan Student Internship Program pada Indsutri perjalanan berbasis Umroh dan Haji dimana peserta didik melayani dan menangani dokumen pasasi domestik.

Kurikulum merupakan rencana yang strategis yang bermuara pada hasil akhir yaitu "outcome" yang dihasilkan oleh Program Studi, begitu pentingnya sebuah kurikulum belum dilakukan pengembangan dalam hal ini kurikulum bersifat dinamis dan menyusuaikan dengan kebutuhan peserta didik. Hal yang dilaksanakan oleh Program Studi Usaha Perjalanan Wisata pada Politeknik Pariwisata Makassar belum melakukan Analisa Situasi sehingga peserta didik, masyarakat dapat merasakan perubahan dalam beberapa aspek seperti peningkatan Kemampuan dan pengetahuan operasional serta etika dalam pelayanan. Kurikulum yang dijalankan belum dilaksanakannya analisa terhadap Rencana Pembelajaran Semester yang dibuat oleh dosen/pengajar atau pengampu mata kuliah pada Program Studi Usaha Perjalanan Wisata Diploma 4. Kesenjangan antara kebutuhan peserta didik dan kebutuhan sumber daya manusia yang ada di industri perjalanan wisata tidak memiliki sinergitas. Hal yang menjadi 
kesenjangan pada Program Studi Usaha Perjalanan Wisata belum maksimal adalah pemenuhan kemampuan peserta didik dalam menggunakan Bahasa inggris sehingga beberapa flatform industry perjalanan wisata, teknologi yang menggunakan Bahasa inggris kurang dipahami.

Kebutuhan Sumber Daya manusia usaha jasa perjalanan wisata Makassar, Jakarta \& Bali

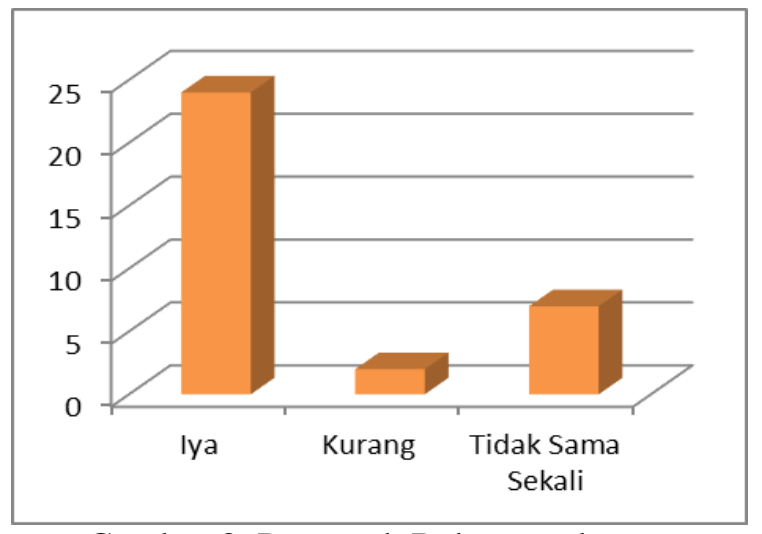

Gambar 8. Pengaruh Bahasa pada saat

kegiatan Student Internship Programm (SIP)

Era revolusi industri 4.0 membuka kesempatan bagi SDM di sektor pariwisata untuk memiliki keahlian yang sesuai dengan perkembangan teknologi terkini. Untuk itu, diperlukan pelaksanaan program peningkatan keterampilan (up-skilling) atau pembaruan keterampilan (reskilling) para tenaga kerja berdasarkan kebutuhan dunia industri saat ini. Berdasarkan hasil wawancara tim peneliti dengan beberapa pelaku industri seperti Nanda P. dari PT Sriwijaya Distrik Makasssar menyampaikan Sumber daya manusia saat ini yang dibutuhkan oleh industri yang memiliki "talent", kemampuan dalam menggunakan Bahasa inggris mengingat Bahasa inggris menjadi Bahasa internasional untuk dapat berkomunikasi serta mata kuliah yang dapat mendukung peserta didik dalam melakukan Student Internship Program khususnya yang ingin berada di industri maskapai penerbangan antara lain Bahasa inggris agar memahami istilah system yang digunakan, Sistem reservasi computer agar peserta didik memahami cara reservasi atau pemesanan tiket melalui CRS (Computerized Reservation System). Robert A. manager pada PT. Wira Tour Makassar yang menekankan sumber daya manusia saat ini sangat membutuhkan Kreatifitas dalam bekerja, dan kemampuan menggunakan bahasa asing sesuai dengan tuntutan industri perjalanan wisata saat ini seperti penggunaan Bahasa Inggris, Spanyol dan Mandarin. Serta mata kuliah pendukung seperti Teknik Pemanduan Wisata agar memahami dasar dalam melayani wisatawan, mampu memberikan informasi dihadapan wisatawan karena orientasi kerja di PT. Wira Tour Makassar adalah Penjualan dan penyelenggaraan paket wisata.

Marca Human resources department Media Nusantara Citra (MNC) Travel Jakarta menjelasan mengenai sumber daya manusia pada usaha perjalanan wisata senantiasa memahami CRS (Computerized Reservation System) Pernyataan ini sesuai dengan keadaan yang ada di Program Studi Usaha Perjalanan Wisata karena hanya menggunakan satu system CRS yaitu Galileo namun pelatihan yang diberikan belum maksimal karena sarana dan prasarana dalam hal ini adalah penyediaan komputer dan sistem belum seiring dengan jumlah peserta didik. Dari sisi antusias peserta didik juga diminta untuk lebih aktif dalam mengetahui sistem yang digunakan di MNC Travel Jakarta. Dika Human resources department Pacto Travel Bali menjelasan bahwa sumber daya manusia yang saat ini dibutuhkan adalah kemampuan Bahasa Inggris untuk mendukung pelayanan wisatawan baik di kantor maupun di lapangan. Bahasa Inggris juga dapat menjadi nilai tambah bagi peserta didik agar dapat memahami segala bentuk kerja yang diberikan baik pada operasional, pelayanan bahkan pengelolaan finansial. Namun hal ini belum maksimal jika melihat keadaan yang terjadi di Program Studi Usaha Perjalanan Wisata mengingat Bahasa inggris sebagai salah satu mata kuliah belum terintegrasi dengan mata kuliah vokasi yang ada.

Pemerintah diharapkan adanya 
kebijakan yang memajukan implementasi Industri 4.0 dengan dihadirkannya lewat investasi teknologi pada proses pembelajaran. Dari sisi pelaku industri. Pelaksanaan kegiatan sertifikasi lewat Uji Kompetensi oleh Lembaga Sertifikasi Profesi Pariwisata di Politeknik Pariwisata Makassar belum terintegrasi dengan kurikulum yang dijalankan oleh Program Studi Usaha Perjalanan Wisata Diploma 4. Mapping kurikulum yang dilaksanakan untuk Certificate III, Certificate IV, Certificate V dan Certificate $V I$ belum terintegrasi dengan mata kuliah dalam kurikulum yang dijalankan sehingga peserta didik belum mengetahui posisi pada komptensi yang diujikan juga tidak memiliki sinergitas pada uji kompetensi yang dilaksanakan, sehingga kompetensi yang dimiliki kadang bersifat "overlapping" atau berulang.

\section{HASIL DAN PEMBAHASAN}

Pada dasarnya industri perjalanan wisata yang ada di Makassar, Bali dan Jakarta mengharapkan peserta didik yang sudah mumpuni dalam hal pola pikir, interaksi dengan lingkungan yang berbeda dengan cara yang mudah dan memiliki pola pemikiran yang terstruktur sehingga kreatifitas, inovasi dapat diberikan kepada pihak industry perjalanan wisata.

\section{Gambaran Usaha perjalanan wisata terutama pada Era Industri Pariwisata 4.0}

Penerapan kurikulum pada Program

Studi Usaha Perjalanan Wisata Diploma seharusnya memiliki kemandirian dalam melakukan kegiatan review kurikulum, analisa rencana pembelajaran semester dengan mendatangkan beberapa pihak seperti pihak industri perjalanan, akademisi, alumni dan peserta didik dengan cara mengundang, berdiskusi, dan menerima masukan dari pihak Pentahelix dalam hal pengembangan Rencana pembelajaran semester sebagai analisa kebutuhan industri.

Kurikulum vokasi pada Program Studi Usaha Perjalanan Wisata Politeknik Pariwisata Makassar Pariwisata Makassar

Penerapan kurikulum yang sesuai dengan kebutuhan industri perjalanan wisata dapat memberikan peluang yang besar bagi "Outcome" Program Studi Usaha Perjalanan Wisata dapat bekerja sesuai bidangnya dan professional. Penerapan teknologi, digitalization based on learning akan menjadikan kurikulum yang dijalankan sempurna hal ini didasari agar tersedianya sarana dan prasaran di Program Studi Usaha Perjalanan Wisata Diploma 4.

\section{Kebutuhan Sumber Daya Manusia usaha jasa perjalanan wisata}

Pelaksanaan Student Internship Programm seharusnya dilaksanakan dalam 2 (dua) periode yakni periode pertama pada semester 4 (empat) atau 5 (Lima) dengan tujuan mahasiswa dapat memahami dan mengaplikasikan dari sisi pelayanan, Operasional dan Kemampuan pengolahan Finansial di indutri. Sedangkan pada periode selanjutnya yaitu di Semester 8 (Delapan) mahasiswa kembali lagi ke industri dengan pencapaian tujuan memahami dan dapat menjalankan Manajerial di industri bahkan mereka dapat langsung bekerja di industri perjalanan, sehingga Outcome dapat sesuai dengan profil lulusan Program Studi.

Dalam hal penguasaan Bahasa asing khususnya pada Bahasa Inggris saat ini yang dibutuhkan oleh Program Studi Usaha Perjalanan Wisata Diploma 4, harus mengaplikasikan Bahasa Inggris yang bermuara pada Bahasa Inggris Profesi Perjalanan sehingga Platform sistem dalam industri perjalanan dapat diketahui oleh peserta didik. Hal ini juga diharapkan adanya integrasi antara mata kuliah Bahasa Inggris dengan mata kuliah Vokasi pada Program Studi Usaha Perjalanan Wisata sehingga kompetensi yang diberikan dapat sesuai dengan kebutuhan pengajaran terlebih pada kebutuhan industry perjalanan wisata.

dengan tumbuhnya Start $U p$ yang membutuhkan sumber daya manusia yang dapat mengikuti tren percaturan global, seharusnya Program Studi Usaha Perjalanan Wisata Diploma 4 dapat mengundang, berdiskusi, dan menerima masukan dari pihak Pentahelix dalam hal pengembangan RPS dan melakukan analisa kebutuhan industry. Dengan program yang seperti ini kurikulum yang dijalankan sesuai dengan kebutuhan industri perjalanan dan Program studi Usaha Perjalanan Wisata Diploma 4 dapat menghasilkan "Outcome" yang sesuai dibidangnya.

\section{KESIMPULAN DAN SARAN Kesimpulan}

1. Gambaran Usaha perjalanan wisata terutama pada Era Industri Pariwisata 4.0 dalam peningkatan eksistensinya di indutri 
pariwisata berbenah diri dengan memiliki kemampuan sumber daya manusia yang mampu berkiprah, memiliki inovasi, serta kompetensi yang memadai dalam melayani wisatawan domestik maupun mancanegara.

2. Kurikulum vokasi pada Program Studi Usaha Perjalanan Wisata Politeknik Pariwisata Makassar yang dilaksanakan saat ini membutuhkan pengembangan kurikulum.

3. Kebutuhan Sumber Daya Manusia usaha jasa perjalanan wisata yang ada Makassar, Jakarta \& Bali untuk Up-Skilling pemenuhan kompetensi yang berbasis teknologi yang berintegrasi dengan pelaksanaan Uji Kompetensi belum seiring dengan Mapping kurikulum dan kebutuhan dan sinergitas dengan Pentahelix.

\section{Saran}

1. Perlunya meningkatkan eksistensinya dengan memiliki kemampuan sumber daya manusia yang mampu berkiprah, memiliki inovasi, serta kompetensi dalam melayani wisatawan domestik maupun mancanegara sebagai gambaran menghadapi era industry 4.0 sebagai gambaran Usaha perjalanan wisata pada Era Industri Pariwisata 4.0

2. Kurikulum vokasi pada Program Studi Usaha Perjalanan Wisata Politeknik Pariwisata Makassar yang dilaksanakan saat ini membutuhkan pengembangan kurikulum.

3. Kebutuhan Sumber Daya Manusia usaha jasa perjalanan wisata yang ada Makassar, Jakarta \& Bali untuk Up-Skilling pemenuhan kompetensi yang berbasis teknologi yang berintegrasi dengan pelaksanaan Uji Kompetensi agar seiring dengan Mapping kurikulum dan kebutuhan dan sinergitas dengan Pentahelix.

\section{DAFTAR RUJUKAN}

Ali, M. (2009). Pendidikan untuk Pembangunan Nasional. Jakarta : Grasindo.

Edi Fakhri \& Yufridawati. (2010). Relevansi Kompetensi dan Tingkat Daya Saing Lulusan SMK Dalam Dunia Kerja. Jurnal Penelitian Kebijakan pendidikan. Vol.9.

Geriya, Wawan.(1983) Pariwisata dan SegiSegi Sosial Budaya Masyarakat Bali. Denpasar: Udayana

Rakib, Muhammad dan Yusar Toatubun.
(2017). Relevansi Kurikulum Pendidikan Kejuruan dengan Kebutuhan Dunia Usaha di Era AEC,

Ismayanti. (2010). Pengantar Pariwisata. Jakarta: PT Gramedia Widisarana Indonesia.

Musanef. (1996). Manajemen Usaha Pariwisata di Indonesia. Jakarta: PT. Gunung Agung

Rosita, Oktaviani. (2009). Sejarah Kurikulum Indonesia. Diakses dari http:// Sejarah\%20Kurikulum\%20Indonesia.ht $\mathrm{m}$. Pada tanggal 10 November 2019Sugiyono. 2005.

Undang - Undang RI No 10 Tahun 2009 Tentang Kepariwisataan

Undang-Undang RI No.20 tahun 2003, tentang Sistem Pendidikan Nasional.

Pendidikan Vokasi (http://ub.ac.id) diakses pada 01 November 2019

Peraturan Pokok Pengusulan Perusahaan Perjalanan SK.242/HI1970 Tanggal 05 Agustus 1970

Pengembangan Pariwisata 4.0 (imam.web.id/pengembangan pariwisata.4.0) di akses 19 November 2019 